\title{
Histological study of the gonadal development of Ruditapes decussatus (L.) (Mollusca: Bivalvia) and its relationship with available food*
}

\author{
MARINA DELGADO and ALEJANDRO PÉREZ CAMACHO \\ Instituto Español de Oceanografía, Muelle de Ánimas s/n, 15001, La Coruña, Spain. E-mail: alejandro.perez@co.ieo.es
}

\begin{abstract}
SUMMARY: This article describes the effects of food availability on the sexual maturation of Ruditapes decussatus through histological examination of the gonadal tissue. Three food rations were tested: High (H: $1 \mathrm{mg}$. organic matter. $\mathrm{g}$ live weight ${ }^{-1}$.day ${ }^{-1}$ of the microalgae Isochrysis galbana clone T-ISO), intermediate (I: $0.5 \mathrm{mg} \mathrm{OM} \mathrm{g} \mathrm{live} \mathrm{weight}{ }^{-1}$ day $\left.^{-1}\right)$ and nutritionally restricted (R: $0.25 \mathrm{mg} \mathrm{OM}$ g live weight $^{-1} \mathrm{day}^{-1}$ ). The tests were carried out at a constant temperature of $18^{\circ} \mathrm{C}$ for a period of 70 days for diets $\mathrm{H}$ and I, and 120 days for diet $\mathrm{R}$. The results showed that in $R$. decussatus the energy from ingestion was mainly channelled to reproductive processes, especially when food was restricted. The clams matured sexually under all the conditions tested, both with a somatic growth and with a loss of body mass. The available food was directly related to the rate of the gonadal development and with the total quantity of gonad generated. Equally, food restrictions limited gonadal recovery after spawning episodes. Food quantity also affected the dry weight of soft tissues (DW), which increased with the highest ration $(\mathrm{H})$ and decreased notably with the lowest ration $(\mathrm{R})$. Decreases in DW when food was scarce appeared to be more related to loss of reserve tissue rather than to variations in the quantity of reproductive tissue.
\end{abstract}

Key words: Ruditapes decussatus, food availability, gonadal development, histology, maturity index.

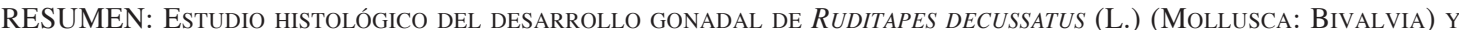
LA RELACIÓN CON EL ALIMENTO DISPONIBLE. - Este artículo describe los efectos de la disponibilidad de alimento en la maduración sexual de Ruditapes decussatus, a través del examen histológico del tejido gonadal. Se ensayaron tres raciones de alimento: Alta (H: 1 mg. materia orgánica. g live weight ${ }^{-1}$.day ${ }^{-1}$ de la microalga Isochrysis galbana clone T-ISO), intermedia (I: $0.5 \mathrm{mg} \mathrm{OM} \mathrm{g}$ live weight ${ }^{-1}$ day $^{-1}$ ) y de restricción nutricional (R: $0.25 \mathrm{mg} \mathrm{OM} \mathrm{g} \mathrm{live} \mathrm{weight}{ }^{-1}$ day $^{-1}$ ). Los ensayos se realizaron a una temperatura constante de $18^{\circ} \mathrm{C}$, y se prolongaron por un periodo de 70 días en el caso de las experiencias H e I, y de 120 días en el caso de la experiencia R. Los resultados muestran que en $R$. decussatus, la energía procedente de la ingestión se destina prioritariamente al proceso reproductivo, sobre todo en situaciones de restricción alimentaria. De esta forma, las almejas maduran sexualmente bajo todas las condiciones ensayadas, tanto en las que determinan un crecimiento somático, como en aquellas que producen una pérdida de masa corporal de las almejas. No obstante, el alimento disponible guarda relación directa con la velocidad del desarrollo gonadal y con la cantidad total de gónada generada. Igualmente, las restricciones de alimento pueden limitar las recuperaciones gonadales tras los episodios de puesta. La cantidad de alimento disponible repercute también en el peso seco de los tejidos blandos (DW), que se incrementa en la ración más elevada $(\mathrm{H})$ y disminuye notablemente con la ración más baja $(\mathrm{R})$. Estas caídas en el DW cuando escasea el alimento, parecen estar más relacionadas con pérdidas de tejido de reserva que con variaciones de la cantidad de tejido reproductivo.

Palabras clave: Ruditapes decussatus, disponibilidad de alimento, desarrollo gonadal, histología, índice de madurez.

*Received January 12, 2004. Accepted September 15, 2004. 


\section{INTRODUCTION}

The fundamental role that the combined action of temperature and feeding exercise on the gametogenic process of a large number of bivalve molluscs has been widely studied. Temperature is normally responsible for initiating gonadal development, whereas food supply determines the extension of the reproductive process (Lubet, 1959).

Reproduction is a process requiring abundant energy for gonadal development. Reproductive success depends directly on the food ingested or on previously stored reserves. A few studies, such as those for Chlamys septemradiata (Ansell, 1974) and Ostrea edulis (Ruíz et al., 1992), have described the influence of feeding on the development and duration of the reproductive cycle. However, some authors have reported the disadvantageous effects of food shortage on the reproductive activity of certain species (Mytilus edulis and Aequipecten irradians), which may cause the suppression of gonadal development (Sastry, 1968; Gabbott and Bayne, 1973; Bayne et al., 1978).

Similarly, the effects of diverse environmental parameters, such as food and temperature, on the development of the gonadal tissue have been studied in some species of bivalve molluscs under controlled conditions (Bayne, 1975; Bayne et al., 1978; Chaparro, 1990). However, there is currently no established relationship between food availability and gonadal development in $R$. decussatus or other Veneridae from the strictly histological point of view, despite abundant information concerning their reproductive cycle in natural populations (Pérez-Camacho, 1980; Beninger, 1982; Shaffee and Daoudi, 1991; Villalba et al., 1993; Xie and Burnell, 1994; Laruelle et al., 1994; Rodríguez-Moscoso, 2000).

In view of the fact that feeding is a determining factor for gonadal development in bivalves, our principal objective was to histologically study sexual maturation in $R$. decussatus. Three contrasting conditions of food availability were examined, high, intermediate and nutritionally restricted, which could cause situations ranging from an increase in body mass ( $\mathrm{H}$ : high ration) to a substantial loss in the soft tissue weight of the clams (R: nutritionally restricted ration) (Pérez Camacho, 1980; Delgado, 2002; Delgado and Pérez Camacho, 2002; Delgado and Pérez-Camacho, 2003; Pérez Camacho et al., 2003).

\section{MATERIALS AND METHODS}

\section{Design and experimental conditions}

The experiments were carried out using adult specimens of Ruditapes decussatus, with a mean initial length of $36 \pm 0.19 \mathrm{~mm}$, collected from the intertidal environment from Ría de Arousa (Galician coast, Spain). The clams were placed in 121 plastic tanks, in a flow-through circuit containing natural sea-water filtered through a $1 \mu \mathrm{m}$ mesh. Temperature $\left(18^{\circ} \mathrm{C}\right)$ and salinity $(33 \%)$ were maintained constant in all the experiments. Food was supplied to the clams on a continuous basis by means of a variable-flow peristaltic pump. We assayed 3 daily food rations of the microalgae Isochrysis galbana (clone T-ISO): high ration (H: $1 \mathrm{mg}$. organic matter.g live weight ${ }^{-1}$ ), intermediate ration (I: $0.5 \mathrm{mg}$ OM. g live weight ${ }^{-1}$ ) and nutritionally restricted (R: $0.25 \mathrm{mg} \mathrm{OM}$. g live weight ${ }^{-1}$ ).

Samples were taken at the beginning of the experiment and at 21, 41, 70 and 120 days (ration R). On each occasion, 10 specimens were examined to determine soft-tissue dry weight (DW), with a further 10 specimens taken for histological studies. Where necessary, the number of specimens per sample was increased in order to obtain a minimum of 4 specimens for each sex. The initial number of specimens was 100 for rations $\mathrm{H}$ and $\mathrm{I}$, and 140 for ration R.

\section{Histology}

Tissues were fixed in Bouin's fluid, dehydrated and embedded in paraffin. Four $\mu \mathrm{m}$ sections were prepared and stained with Harris's hematoxyline and eosine (Bancroft and Stevens, 1996). Several gametogenic developmental stages in $R$. decussatus were identified as a function of the phases proposed for Veneridae by Holland \& Chew (1974), Gallois (1977), Devauchelle (1990) and Shaffee and Daoudi (1991). The general defining characteristics are:

- Period of sexual rest (I): gonadal follicles are absent and connective and muscular tissue occupies the entire zone from the digestive gland to the foot. There is no evidence of gonadal development and sex determination is not possible.

- Initiation of gametogenesis (II): follicles and gonadal acini begin to appear in females and males respectively. They increase in size, and appear covered with oocytes in the growth phase in the females and with immature gametes (spermatogonia and spermatocytes) in the males. 
- Advanced gametogenesis (III): The follicles occupy a large part of the visceral mass. The presence of muscular and connective tissue is reduced. At the end of this stage, characterised by intense cellular growth in females, the oocyte protrudes from the centre of the lumen, remaining attached to the wall via the peduncle. The abundance of free oocytes equals those attached to the wall of the follicle. In males, the majority of the acini were full of spermatids and spermatozoids.

- Reproduction period (IV): corresponding to the maturity of the majority of gametes. In the mature oocytes the rupture of the peduncle occurs, and the oocytes consequently occupy the follicular interior. In males, the gonadal acini mainly contain spermatozoids. Throughout this period partial spawning may occur, and it concludes with the total emission of gametes.

One of the peculiarities which define the gonadal development of this species is the simultaneous presence of totally mature individuals and individuals in phases of non-advanced gametogenesis. Accordingly, an index was calculated which represents the degree of maturity corresponding to each sample and experimental condition. To determine the maturity index (M.I), four grades of gametogenic development were established, according to the above scale. Assigning a value to each gives: $1=$ period of sexual rest; $2=$ initiation of gametogenesis; 3 = advanced gametogenesis and $4=$ reproduction period. The following expression was thus applied to calculate the percentage of mature individuals:

M.I $=\left(\right.$ Sum of $\mathrm{n}^{\circ}$ individuals $*$ category $) / \mathrm{n}^{\circ}$ total individuals

\section{Dry weight of soft tissues}

In each sample, the clams were measured and weighed, and their sex was determined through microscopic examination of a tissue smear. Thereafter, the adductor muscles were cut and the clams were placed on their ventral surface, allowing them to drain for 5 minutes. The soft tissues were separated and freeze dried, taking the freeze-dried weight as dry weight (DW). The dry weight coefficient with respect to the initial datum (DW/DW initial) was also calculated.

\section{Statistical methods}

Dry weight comparisons between the distinct feeding conditions were achieved via analysis of variance (ANOVA) at a significance level of $95 \%$. Homogeneity of the variances was guaranteed through the Cochran test. The statistical analyses were performed with the program Statgraphics Plus 5.0, employing the statistical methods of Snedecor and Cochran (1980).

\section{RESULTS}

\section{Initial state}

All the experiments ( $\mathrm{H}, \mathrm{I}$ and $\mathrm{R}$ ) began either with sexually indifferent individuals (phase I) or those displaying signs of gametogenesis (phase II) (M.I=2; Fig.5).

In females, the follicles were small and few in numbers. Oogonias and young oocytes were mainly found on the follicle walls with an occasional free mature oocyte in the centre of the lumen (Figs. 1a, $2 \mathrm{a}$ and $3 \mathrm{a}$ ). In males the acini, which provide a space between the muscular fibres and the connective tissue, were also scarce (Figs. 1e, 2d and 4a). The acini largely contained immature gametes.

For both females (Figs. 1a, 2a and 3a) and males (Figs. 1e, 2d and 4a), numerous vesicular cells filled the developing follicles and acini and surrounded the germinal cells in the first phases of gametogenesis. This illustrates the important energetic contribution of this cellular type in the initial stages of development. The intrafollicular vesicular cells scarcely appeared in the subsequent samples. The interfollicular, connective and muscular tissue surrounding the follicles and developing acini, analogous to muscular tissue sustaining the gonad, was abundant and occupied almost the entire space between the digestive gland and foot.

\section{Experiment $\mathbf{H}$}

\section{Females}

Almost all individuals fed with ration $\mathrm{H}$ showed intense gametogenic development (phase III) 21 days after the start of the experiment (Fig. 1b). The interfollicular connective and muscular tissue was still abundant and bordered the follicles, which increased in size and number. The follicles began to fill with oocytes, which detached from the walls, with similar proportions of mature and immature gametes.

After 41 days (Table 1, Fig. 5), all the clams were in reproduction period (M.I=4) and mature 

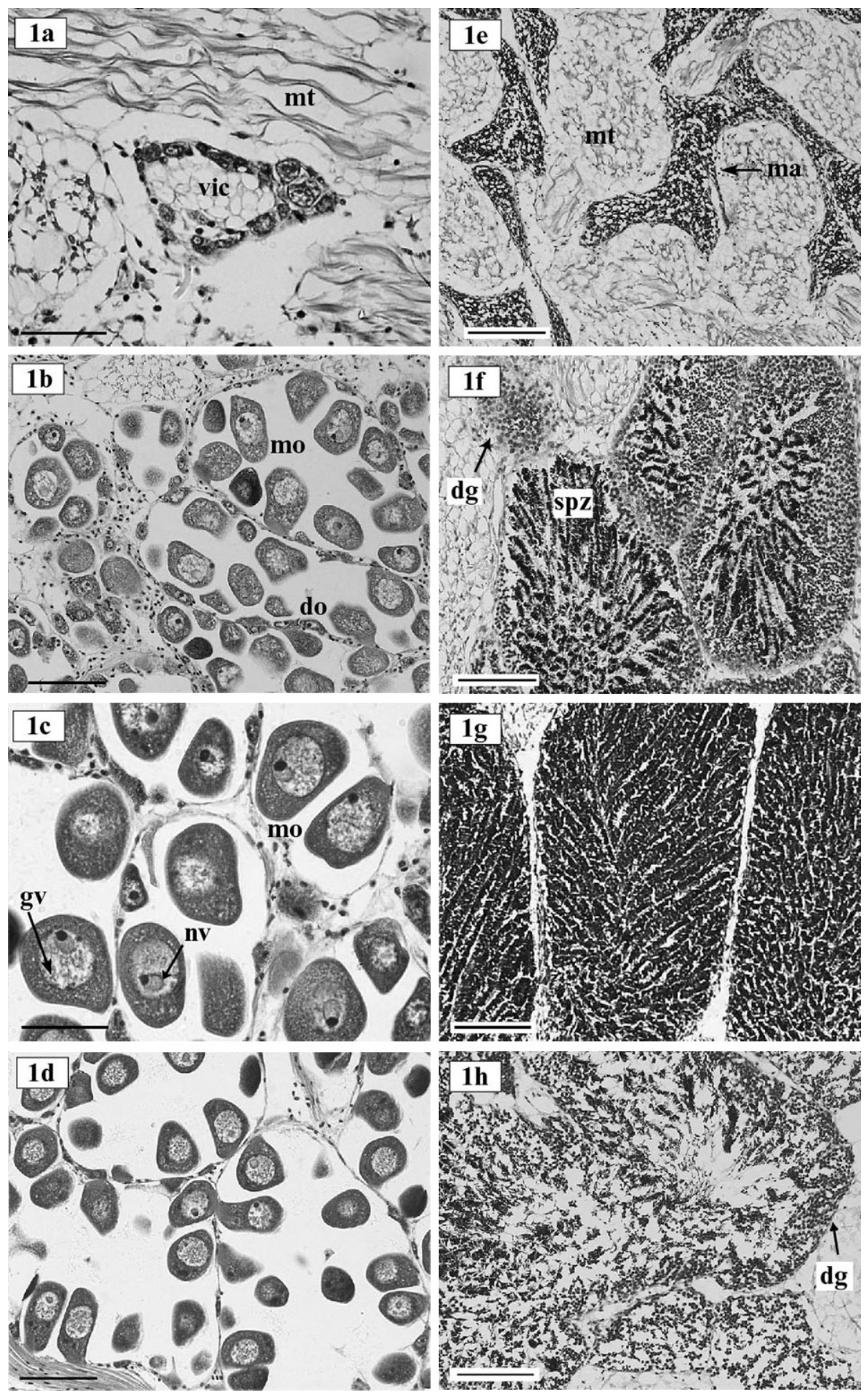

FIG. 1. - Gonad from individuals belonging to experiment H. Females: 1a) Start of experiment H: Phase II of gametogenic development. 1b) 21 days: Phase III. 1c) 41 days: Phase IV, detail of mature oocytes. 1d) 41 days: Phase IV. Males: 1e) Start of experiment H: Phase II. 1f) 21 days: Phase III. 1g) 41 days: Phase IV, totally mature individual. 1h) 41 days: Phase IV, detail of indications of partial spawning. Abbreviations: dg: developing gametes; do: developing oocyte; gv: germinal vesicle; ma: male acini; mo: mature oocyte; mt: muscular tissue; nv; nuclear vacuole; spz: spermatozoids; vic: vesicular intrafollicular cells. Scale bar $=75 \mu \mathrm{m}$ (Fig. 1a and c); 150 $\mu \mathrm{m}$ (Fig. 1b, d, e, f, g and h).

oocytes were abundant and released in the lumen of the follicle. The size and appearance of the germinal vesicle and the presence of the nucleolar vacuole in the oocytes (Fig. 1c) are clear indications of advanced vitellogenesis, as reported by Longo and Anderson (1969) for Mytilus edulis. 

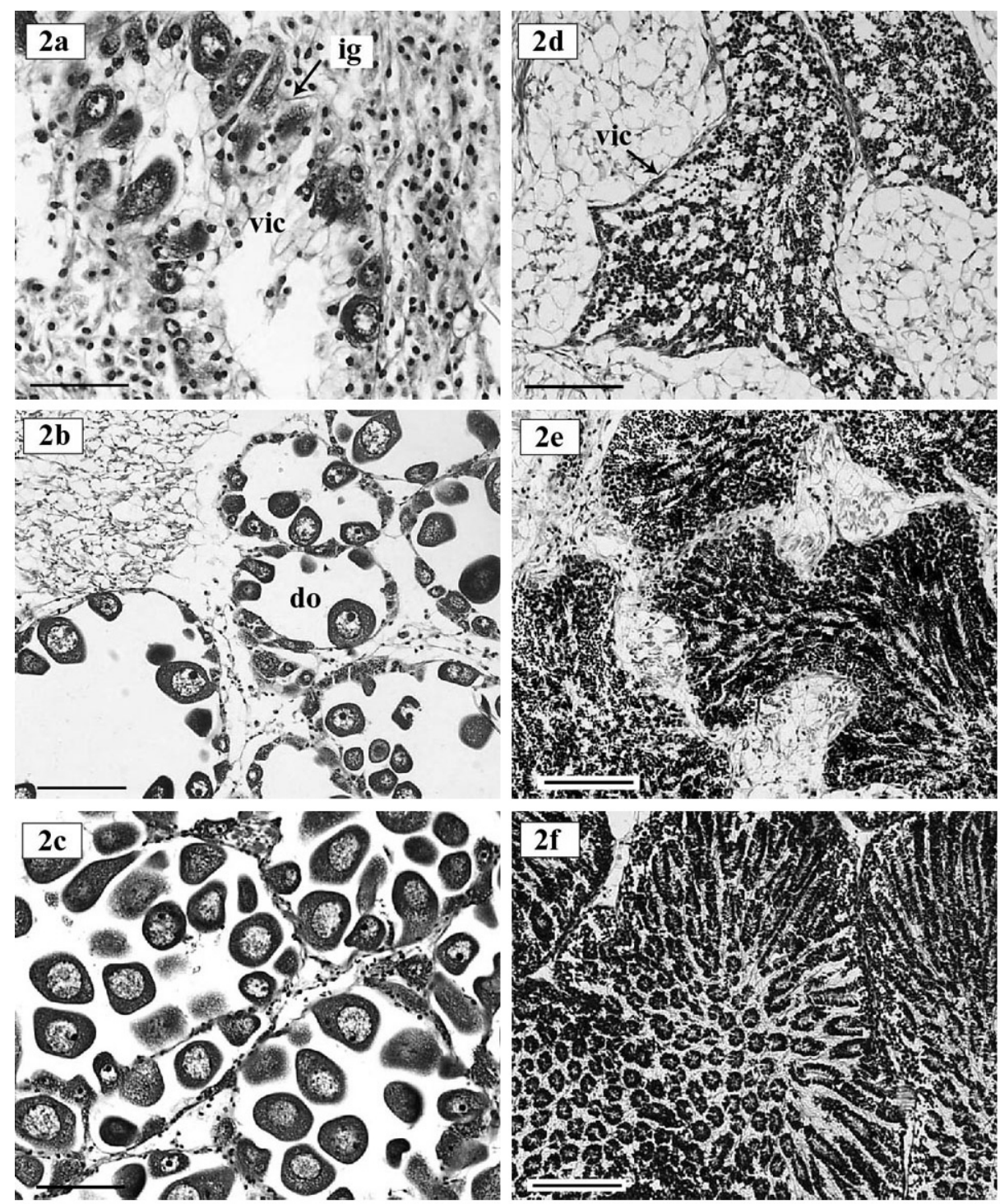

FIG. 2. - Gonad from individuals belonging to experiment I. Females: 2a) Start of experiment I: Phase II of gametogenic development. 2b) 21 days: Phase III. 2c) 41 days: Phase IV. Males: 2d) Start of experiment I: Phase II. 2e) 21 days: Phase III. 2f) 41 days: Phase IV. Abbreviations: ig: immature gametes; do: developing oocyte; vic: vesicular intrafollicular cells. Scale bar $=75 \mu \mathrm{m}$ (Fig. 2a and d); $150 \mu \mathrm{m}$ (Fig. $2 \mathrm{~b}$, $\mathrm{c}, \mathrm{e}$ and $\mathrm{f}$ ).

The free oocytes forced a polygonal appearance in the follicles due to accumulating pressure. Semi-empty zones were also evident as a consequence of partial emission of gametes (Fig. 1d). Interfollicular connective and muscular tissue was scarce.

After 70 days (Table 1, Fig. 5), $100 \%$ of female clams continued mature in phase IV (M.I=4) and continual partial spawning was observed, leading to a reduction in the number of free oocytes in the centre of the lumen. The follicular walls were thinner and occasionally split open due to expulsion of gametes. In addition, the presence of new germinal layers in development was noted.
Males

During the experiment the gonadal acini with developing spermatocytes, spermatids and a quantity of spermatozoids extended throughout the zone between the digestive gland and the foot (phase III). From day 21 the diameter of the acini increased considerably and large quantities of spermatozoids accumulated within. Spermatogenesis and spermiogenesis developed centripetally, and the spermatozoids eventually became organised in a rosette formation (Fig. 1f). The presence of interfollicular muscular and connective tissue was still evident, although it had almost disappeared in the subsequent sample. 


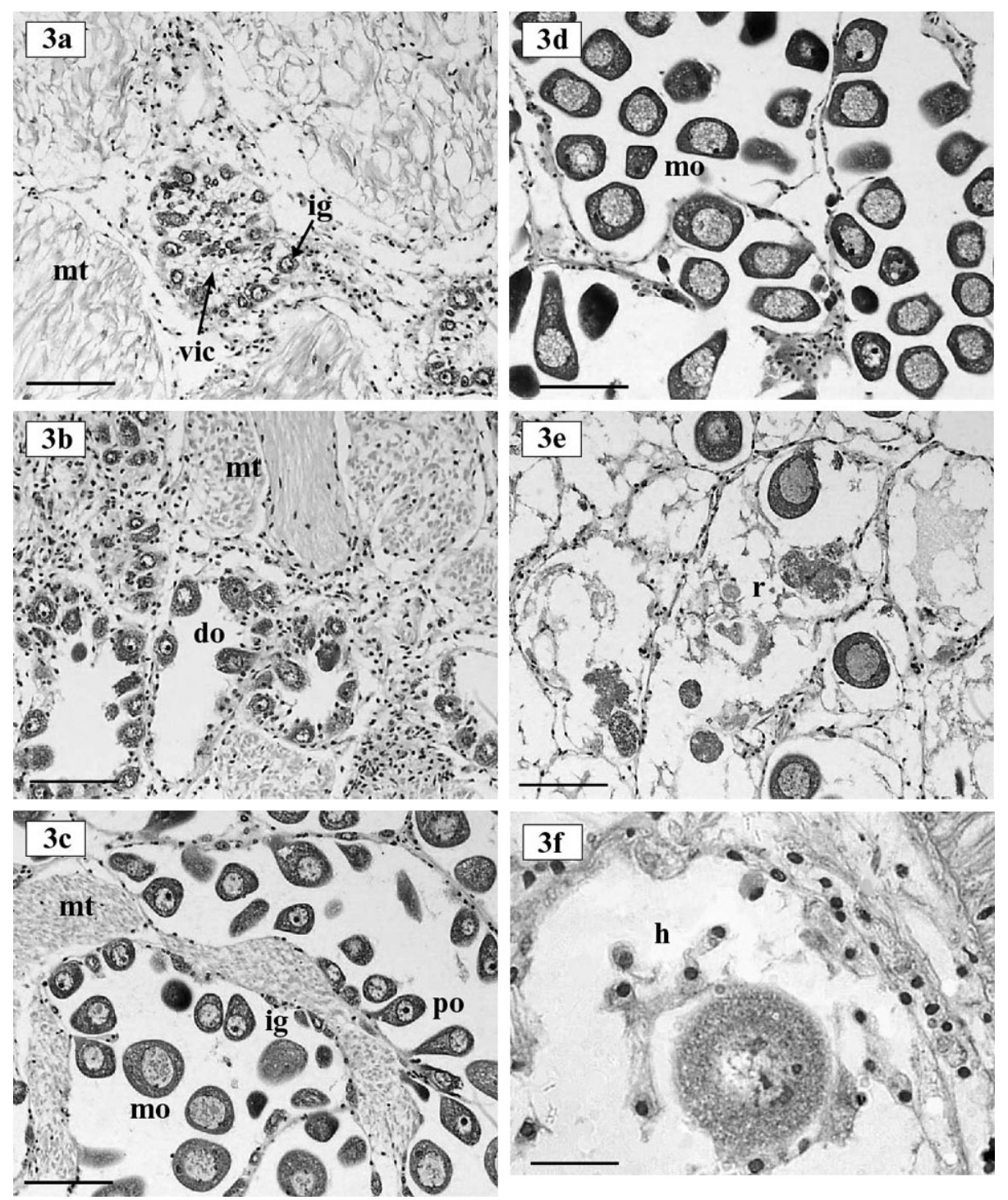

FIG. 3. - Feminine gonad of individuals belonging to experiment R. 3a) Start of the experiment: Phase II of gametogenic development. 3b) 21 days: Phase II. 3c) 41 days: Phase III. 3d) 70 days: Phase IV, reproduction period. 3e) 120 days: Period of post-spawning. 3f ) 120 days: Detail of oocyte surrounded by hemocytes. Abbreviations: do: developing oocyte; h: hemocytes; ig: immature gametes; mo: mature oocyte; mt: muscular tissue; po, pedunculated oocyte; r: residuals from cytolisis; vic: vesicular intrafollicular cells. Scale bar $=20 \mu \mathrm{m}$ (Fig. 3f); $150 \mu \mathrm{m}$ (Fig. 3a, b, c, d and e).

Finally, from day $41,100 \%$ of the males were totally mature (M.I=4) (Fig. $1 \mathrm{~g}$ and 5, Table 1). The coexistence of acini full and empty of spermatozoids was noted, the latter with ruptured walls from gamete emission (Fig. 1h). Layers of immature gametes in development covering the acini were still evident.

\section{Experiment I}

\section{Females}

In this experiment with the intermediate food ration (I), a remarkably similar developmental trend to the clams fed with the higher ration $(\mathrm{H})$ was noted. Intense gametogenic development after 21 days (Fig. 2b) was followed by the appearance of totally mature individuals after 41 days (Fig. 2c). However, the percentage of mature individuals was less $(79 \%)$ than with diet $\mathrm{H}(100 \%)$ for the same

TABLE 1. - Percentage of mature individuals (males and females) during 70 days feeding with rations $\mathrm{H}: 1, \mathrm{I}: 0.5$ and $\mathrm{R}: 0.25$ ( $\mathrm{mg} \mathrm{OM} \mathrm{g}^{-1}$ live weight.day $\left.{ }^{-1}\right)$.

\begin{tabular}{lccc}
\hline & & Rations \\
Days & $H$ & $I$ & $R$ \\
\hline 1 & $0 \%$ & $0 \%$ & $0 \%$ \\
21 & $14.5 \%$ & $0 \%$ & $0 \%$ \\
41 & $100 \%$ & $79 \%$ & $33 \%$ \\
70 & $100 \%$ & $100 \%$ & $60 \%$ \\
\hline
\end{tabular}



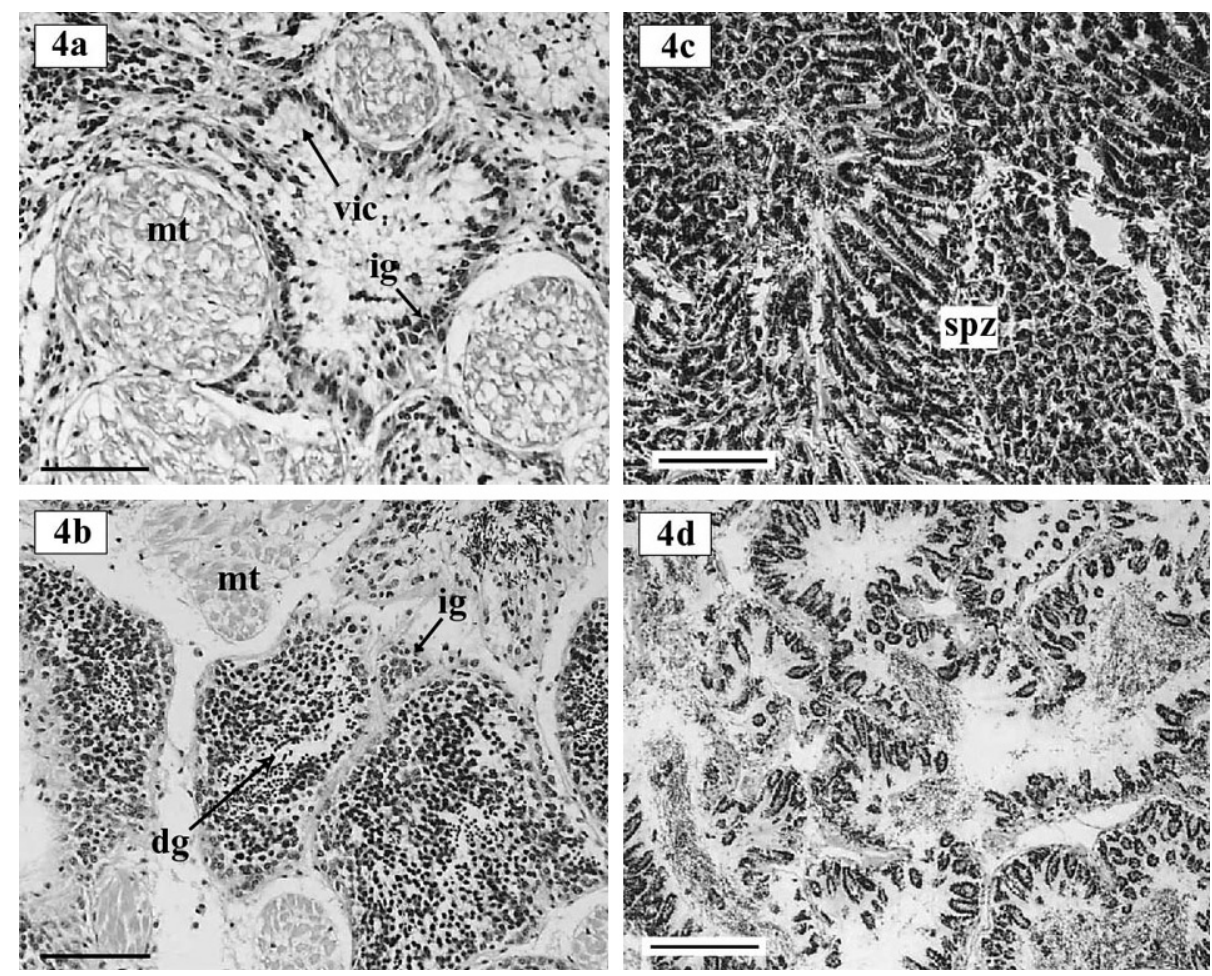

FIG. 4. - Masculine gonad of individuals belonging to experiment R. 4a) Start of the experiment: Phase II of gametogenic development. 4b) 41 days: Phase II. 4c) 70 days: Phase IV. 4d) 120 days: Post-spawning. Abbreviations: dg: developing gametes; ig: immature gametes; mt: muscular tissue; spz: spermatozoids; vic: vesicular intrafollicular cells. Scale bar $=150 \mu \mathrm{m}$ (Fig. 4a, b and c), $200 \mu \mathrm{m}$ (Fig. 4d).

time period (Table 1). After 70 days, all individuals were mature (100\%; M.I=4). Indications of partial gamete emission in both sexes were established, although were less frequent than for experiment $\mathrm{H}$.

\section{Males}

As for females, there were few differences in the gonadal development between nutritional conditions $\mathrm{I}$ and $\mathrm{H}$. After 21 days, the individuals were in phase (III) of intense gametogenic development (Fig. 2e), and most were totally mature after 41 days, showing a maturity index of 3.7 (Fig. 5; Fig. 2f).

\section{Experiment R}

\section{Females}

After 21 days approximately half of the individuals fed with the nutritionally restricted ration (R) were still in initial stages of development (phase II) (Fig. 3b), giving low M.I values of 2.5 (Fig. 5). Despite a greater proportion of individuals in stage III after 41 days (Fig. 3c), some totally mature individuals were observed alongside individuals which had not yet completed gametogenic development. In fact, only $33 \%$ of the individuals had matured, whereas for rations $\mathrm{H}$ and I after the same time period $100 \%$ and $79 \%$ of individuals were mature respectively. The presence of mature individuals increased at day 70 (Fig. 3d and Table 1; M.I=3.6), but in contrast to the higher rations no signs of partial spawning were observed.

Due to delay in development of individuals from this test compared to those fed with the higher food rations (H and I) (Table 1 and Fig. 5), the experiment was prolonged by 50 days to determine the effects of the deficient ration over a longer period. After a total of 120 days, the gonad showed aspects of post-spawning (Fig. 3e). Totally empty zones were observed as well as the occasional presence of mature oocytes (not emitted). The follicular walls occasionally appeared to be broken, and did not show an active germinal layer for future gonadal recuperation. In addition, the rupture of cellular membranes with dispersal of oocyte wastes was also observed. In the interior of the gonadal follicles an increase in cellular types associated with gametogenic reabsorption was noted: for example, the hemocytes (see Fig. 3f). Together, these characteristics appear to represent gonadal reabsorption following massive spawning. 
Males

After 21 days with the more restrictive feeding level, and again in contrast with the higher rations, a significant number of individuals were in the initial phase of gametogenesis (Fig. 4b), with low numbers in an advanced development phase (Table 1). After 41 days, this proportion was inverted, giving a majority of individuals in stage III (Fig. 5). There was an increase in spermatozoids compared to immature (spermatogonia and spermatocytes) and developing gametes (spermatids), which covered the walls of the gonadal acini. After 70 days, only $60 \%$ of the individuals were in full reproductive mode (phase IV) (Fig. 4c, Fig. 5 and Table 1). At the end of the test period (120 days), the appearance of the individuals was characteristic of post-spawning (Fig. 4d). Acini with large empty spaces, broken walls, and disperse hemocytes are characteristic of gamete reabsorption after spawning.

\section{Dry weight of soft tissues}

Table 2 shows the DW coefficient, compared with the initial datum, under each feeding condition over the test period. As demonstrated, the quantity of food determined the evolution of DW. With the highest ration ( $\mathrm{H}: 1 \mathrm{mg}$ OM. $\mathrm{g}$ live weight $\left.{ }^{-1}\right)$ high DWs were obtained, showing an increase of more than $20 \%$ over the initial datum. Ration I ( $0.5 \mathrm{mg} \mathrm{OM.} \mathrm{g} \mathrm{live} \mathrm{weight}$ $\left.{ }^{1}\right)$ produced only a slight increase in DW. The differences between rations $\mathrm{H}$ and I were statistically significant after the second sample, at 21, 41 and 70 days (ANOVA, $\mathrm{p}<0.05$ ). Conversely, clams fed with the ration $\mathrm{R}\left(0.25 \mathrm{mg}\right.$ OM. $\mathrm{g}$ live weight $\left.{ }^{-1}\right)$ showed a clear progressive decrease in DW throughout the experiment, noting losses of $24 \%$. After 41 days the dry weight fall halted with the ration $\mathrm{R}$.

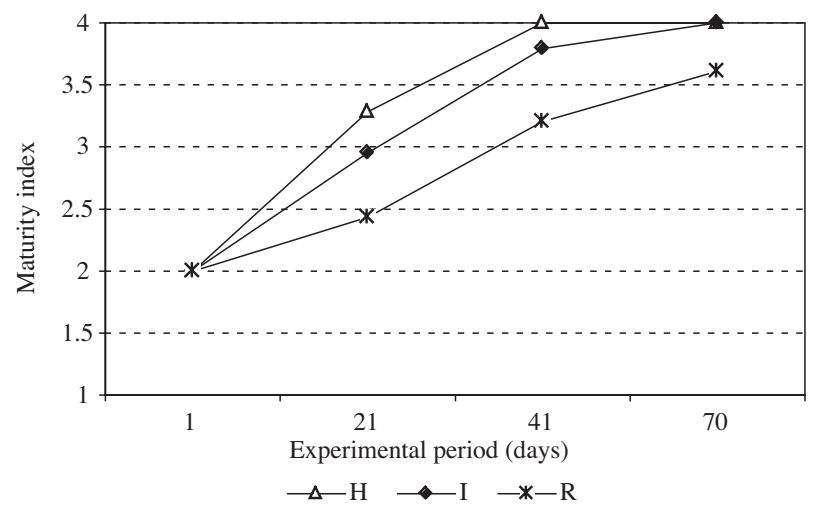

FIG. 5. - Variation of the maturity index (M.I) over 70 days feeding with rations $\mathrm{H}$, I and $\mathrm{R}$.
TABLE 2. - Dry weight coefficient, with respect to the initial datum, for experiments with rations $\mathrm{H}$, I and $\mathrm{R}\left(1,0.5\right.$ and $0.25 \mathrm{mg} \mathrm{OM} \mathrm{g}^{-1}$ live weight.day ${ }^{-1}$ respectively).

\begin{tabular}{lccc}
\hline & \multicolumn{3}{c}{ Rations } \\
Days & $H$ & $I$ & $R$ \\
\hline 21 & $1.10 \pm 0.13$ & $0.99 \pm 0.09$ & $0.90 \pm 0.09$ \\
41 & $1.24 \pm 0.12$ & $1.07 \pm 0.15$ & $0.76 \pm 0.07$ \\
70 & $1.20 \pm 0.15$ & $1.00 \pm 0.08$ & $0.80 \pm 0.12$ \\
120 & & & $0.76 \pm 0.08$ \\
\hline
\end{tabular}

\section{DISCUSSION}

The different situations of food availability, high (H: $1 \mathrm{mg} \mathrm{OM.} \mathrm{g} \mathrm{live} \mathrm{weight}{ }^{-1}$.day ${ }^{-1}$ ), intermediate (I: $0.5 \mathrm{mg} \mathrm{OM}$. g live weight ${ }^{-1}$ day $^{-1}$ ) and nutritionally restricted (R: $0.25 \mathrm{mg} \mathrm{OM}$. g live weight ${ }^{-1}$ day $^{-1}$ ), permitted sexual maturation of Ruditapes decussatus. In all experiments normal gonadal development was observed, and was similar to that described by Laruelle et al. (1994) and Rodríguez-Moscoso (2000) for $R$. decussatus during the reproductive cycle in natural populations. Our results have shown that the quantity of available food within the studied food range did not condition the gonadal development in this species, but modified some defining characteristics of gametogenesis.

One of the peculiarities that define development in this species and other bivalves is the simultaneous presence of individuals in totally mature and less advanced phases of gametogenesis. Using the percentage of mature individuals and the maturity index (M.I) to quantify the extent of development, we noted that over identical time periods these parameters increased with food quantity (Table 1 and Fig.5). In fact, after 41 days a large number of the individuals fed with ration $\mathrm{R}$ were still in developmental phase II or III (Fig. 3c and 4b), whereas individuals sustained with rations $\mathrm{H}$ and $\mathrm{I}$ were totally mature (Fig. 1c, 1g, 2c and 2f). Furthermore, the period of partial emission of gametes, also described by Rodríguez-Moscoso (2000) in natural populations, appeared to be accelerated by more favourable nutritional conditions, since the first indications of partial spawning corresponded to ration $\mathrm{H}$.

The delay in gonadal development in individuals fed with the nutritionally restricted $\operatorname{diet}(\mathrm{R})$ was the rationale for prolonging the experiment. Sexual maturation of these clams did occur, however, showing clear indications of massive spawning after 120 days. We therefore conclude that food supply, 
although not responsible for sexual maturation of the clams, condition the rate of development. A direct relationship between food availability and acceleration of the reproductive process was observed, provided that temperature was favourable. Image analysis results obtained by our group complement and confirm these conclusions, and show that the amount of available food influences the rate of gonadal maturation of this species (Delgado and Pérez-Camacho, 2003). Accordingly, Buchanan et al. (1998) and Kent et al. (1998) related the rapid gametogenic development of Crassostrea virgínica and Katelysia scalarina respectively, with optimum feeding conditions. In fact, differences in the feeding conditions could partly explain interannual variations (Navarro et al. 1989) or variability between distinct geographical points in the reproductive trend of a species. Jaramillo et al. (1993) associated the spawning period in Chalmys amandi with high food levels rather than water temperature, and, as reported by Seed (1976), the spawning period in bivalves could be synchronised with the maximum food abundance for favouring the posterior development of the larvae.

Rodríguez-Moscoso (2000) studied the reproduction of Ruditapes decussatus in natural populations, and concluded that the gametogenic reabsorption phenomenon was unimportant. Our tests showed insignificant presence of hemocytes (cells responsible for reabsorption processes, GarcíaDomínguez et al., 1998; Berthelin et al., 2000) and cellular wastes (indicators of gamete phagocytosis in the interior of the gonadal follicles) throughout gonadal development. Reabsorption (Fig. 3f) was more related to post-spawning than to gonadal recession caused by nutritional insufficiency, responding to a process of follicular regeneration after a spawning or to the preparation of the gonad before initiating a new period of sexual rest. According to Bayne (1975) and Bayne et al. (1978), however, their experiments of starvation with Mytilus edulis concluded with the reabsorption of spermatozoids and oocytes in the final phase of development and, consequently, with gonadal recession. In our studies, suppression of gonadal development was not observed. Individuals belonging to this experiment $(\mathrm{R})$, matured after a delay and endured spawning episodes. Nevertheless, differences between the biological cycles and the anatomical characteristics of the gonad of M. edulis and $R$. decussatus may partly explain the distinct reproductive behaviour of these species under stress effects.
Our results suggest that a further consequence of nutritional limitation during gonadal development may be a lack of renovation of the germinal layers, which assure gonadal recovery after partial or total emission of gametes. The characteristics and physiology of the oocyte and, consequently, fecundity and larval viability should also be directly affected by nutritional deficiencies (Bayne et al., 1978; Pipe, 1985). The morphology of the oocyte did not appear to be affected by the feeding availability in our studies (Delgado and Pérez-Camacho, 2003). Nevertheless, future studies on the effects of serious nutritional deficiencies on the viability of eggs and larvae of this species would clearly be of interest.

For both males and females, we also observed a disappearance of the muscular and interfollicular connective tissue and the intrafollicular vesicular tissue during the progression of gametogenic development, as reported for Veneridae by Medhioub (1986) and Rodríguez-Moscoso (2000). The energetic role described for these cellular types appears to be restricted to the earlier stages of gametogenesis.

The evolution of the dry weight of soft tissues (DW) was also clearly conditioned by food abundance. The three experiments constituted very different situations and may be envisaged as positive, zero and negative energy balance (Bayne and Newell, 1983; Delgado and Pérez-Camacho, 2003). The high ration (H: $1 \mathrm{mg} \mathrm{OM.} \mathrm{g} \mathrm{live} \mathrm{weight}{ }^{-1}$. day ${ }^{-1}$ ) showed a considerable increase in DW, which can be interpreted as general tissue and gonadal growth. The intermediate ration (I: $0.5 \mathrm{mg}$ OM. g live weight ${ }^{-1} \cdot$ day $^{-1}$ ) may be interpreted as a maintenance ration, since DW was approximately constant. In addition, the energy supply of the nutritionally restricted ration (R: $0.25 \mathrm{mg}$ OM. g live weight ${ }^{1}$.day ${ }^{-1}$ ) did not satisfy the basic requirements of the organism, causing a decrease in DW during the first 41 days (Table 2). From this date on DW stabilised, probably as a consequence of the decrease in the energy expenditure of the clams, which has a direct relationship with DW (Bayne and Newell, 1983). These differences in energy balance would therefore be responsible for the rate at which the gonadal development occurs in this species.

The direct relationship between the increase in DW and advancement of gametogenesis, reported by various authors in studies of $R$. decussatus in natural populations (Pérez-Camacho, 1980; Arnaíz and Pereira, 1984; Rodríguez-Moscoso, 2000), was established in our study only under favourable nutritional conditions (ration $\mathrm{H}$ ). The decrease in DW for 
experiment $\mathrm{R}$ during the first 70 days did not necessarily reflect the emission of gametes or the total regression in the development of the gonadal tissue, as interpreted by the above authors. Rather, we suggest a loss of reserve (non-reproductive) tissue as a consequence of the deficient feeding regime. The evolution of DW indicates the energy status of the organism, and the volume of gonad produced.

To summarise, provided that the experimental temperature is adequate $\left(18-20^{\circ} \mathrm{C}\right.$; Pérez-Camacho, 1977), $R$. decussatus channels the energy from ingestion mainly to reproduction, especially in nutritionally restricted situations. Thus, the clams were able to sexually mature under the experimental conditions, both with a somatic growth and with a loss of body mass. However, food supply maintained a direct relationship with the rate of gonadal development and with the total quantity of gonad generated (Delgado and Pérez-Camacho, 2003). Equally, food supply restriction can limit the gonadal recovery after spawning episodes.

\section{ACKNOWLEDGEMENTS}

We would like to thank P. Espiñeira, C. Pena, H. Regueiro, and P. Mallo for technical assistance. This study was financed by the project PGIDT 99MAR60401. During this work, M. Delgado was supported by a research personnel training grant from the European Social Fund-Spanish Oceanographic Institute (1998-1999), a grant from the Consello Regulador do Mexillón de Galicia (Board of Control of the Galician Mussel) (2000-2001) and a post-doctoral grant from the Ministry of Education, Culture and Sport of the Spanish government (2002-2004).

\section{REFERENCES}

Ansell, A.D. - 1974. Seasonal changes in biochemical composition of the bivalve Chlamys septemradiata from the Clyde sea area. Mar. Biol., 25:85-99.

Arnaíz, R. and J.R. Pereira. - 1984. Estudio de crecimiento, índice de condición y composición bioquímica de una población de Venerupis decussata (L.), procedente de la costa tunecina y sembrada en la isla de Arousa. Actas do IV Simposio Ibérico de Estudos do Benthos Marinho, 2: 257-266.

Bancroft, J.D. and A. Stevens. - 1996. Theory and practice of histological techniques. Churchill Livingstone (ed.), Nueva York.

Bayne, B.L. - 1975. Reproduction in bivalve molluscs under environmental stress. In: Univ. South Carolina Press, Physiological ecology of estuarine organisms, pp. 259-277. Columbia.

Bayne, B.L., D.L. Holland, M.N. Moore, D.M. Lowe and J. Widdows. -1978 . Further studies on the effects of stress in the adult on the eggs of Mytilus edulis. J. Exp. Mar. Biol. Assoc. UK, 58: 825-841.

Bayne, B.L. and R.C. Newell. - 1983. Physiological energetics of marine mollusc. In: A.S.M. Salenium and K.M. Wilbur (eds.), The Mollusca, 4(1): 407-515. Academic Press, New York.

Beninger, P.G. - 1982. Étude biochemique comparée de deux populations de bivalves. $\mathrm{PhD}$ thesis, Univ. Bretagne Occidentale.

Berthelin, C., K. Kellner and M. Mathieu. - 2000. Storage metabolism in the Pacific oyster (Crassostrea gigas) in relation to summer mortalities and reproductive cycle (West Coast of France). Comp. Biochem. Phys. part B, 125: 359-369.

Buchanan, J.T., G.S. Roppolo, J.E. Supan and T.R. Tiersch. - 1998. Conditioning of eastern oysters in a closed, recirculating system. J. Shellfish Res. 17(4): 1183-1189.

Chaparro, O.R. - 1990. Effect of temperature and feeding on conditioning of Ostrea chilensis (Philippi, 1845) reproductors. Aquacult. Fish. Manage., 21: 399-405.

Delgado, M. - 2002. Maduración sexual en Ruditapes decussatus (L.): Implicaciones energéticas y bioquímicas. $\mathrm{PhD}$ thesis, Univ. Santiago de Compostela.

Delgado, M. and A. Pérez Camacho - 2002. Hermaphroditism in Ruditapes decussatus (L.) (Bivalvia) from the Galician coast (Spain). Sci. Mar., 66(2): 183-185.

Delgado, M. and A. Pérez-Camacho - 2003. A study of gonadal development in Ruditapes decussatus (L.) (Mollusca, Bivalvia), using image analysis techniques: Influence of food ration and energy balance. J. Shellfish Res., 22(2). 435-441.

Devauchelle, N. - 1990. Sexual development and maturity of Tapes philippinarum. In: Verone (ed.), Tapes philippinarum. Biologia e sperimentazione, Regione Veneto-E.S.A.V., pp. 47-62.

Gabbott, P.A. and B.L. Bayne. - 1973. Biochemical effects of temperature and nutritive stress on Mytilus edulis (L.). J. Mar. Biol. Assoc. UK, 53: 269-286.

Gallois, D. - 1977. Sur la reproduction des palourdes, Venerupis decussata (Linné) et des clovisses, Venerupis aurea (Gmelin) de l'étang de Thau (Herault). Vie milieu, 28(2A): 233-254.

García-Domínguez, F, B. Ceballos-Vázquez, M. Villalejo-Fuerte and M. Arellano-Martínez. - 1998. Reproductive cycle of the giant reef clam Periglypta multicostata (Sowerby, 1835) (Pelecypoda: Veneridae) at Isla Espiritu Santo, Baja California Sur, Mexico. J. Shellfish Res., 17(4): 1009-1013.

Holland, D.A. and K.K. Chew. - 1974. Reproductive cycle of the Manila clam (Venerupis japonica) from Hood Canal, Washington. Proc. Nat. Shellfish. Ass., 53-58.

Jaramillo, R., J. Winter, J. Valencia and A. Rivera. - 1993. Gametogenic cycle of the Chiloé scallop (Chlamys amandi). J. Shellfish Res., 12(1): 59-64.

Kent, G.N., B.G. Maguire, Y. Martin, M. Crop and K. Frankish. 1998. Broodstock conditioning, spawning induction and larval rearing of the stepped venerid, Katelysia scalarina (Lamarck, 1818). J. Shellfish Res., 17(4): 1065-1070.

Laruelle, F., J. Guillou and Y.M. Paulet. - 1994. Reproductive pattern of the clams, Ruditapes decussatus and Ruditapes philippinarum on intertidal flats in Brittany. J. Mar. Biol. Assoc. UK, 172: 69-96.

Longo, F.J. and E. Anderson. - 1969. Cytological aspects of fertilization in the lamellibranch, Mytilus edulis. I. Polar body formation and development of the female pronucleus. J. Exp. Zool., 172: 69-96.

Lubet, P. - 1959. Recherches sur le cycle sexuel et l'emission des gametes chez les Mytilides et les Pectinidees (Mollusques bivalves). Rev. Trav. Inst. Peches. Marit., 23: 389-548.

Medhioub, M.N. - 1986. Recherches cytologiques sur le cycle de reproduction et l'evolution des reserves chez la palourde japonaise Ruditapes philippinarum (Adams and Reeve) (Mollusque lamellibranche). PhD thesis, Univ. Caen.

Navarro, E., J.I.P. Iglesias and A. Larrañaga. - 1989. Interannual variation in the reproductive cycle and biochemical composition of the cockle Cerastoderma edule from Mundaca estuary (Biscay, North Spain). Mar. Biol., 101: 503-511.

Pérez-Camacho, A. - 1977. Experiencias en cultivos de larvas de tres especies de moluscos bivalvos: Venerupis pullastra (Montagu), Venerupis decussata (Linnaeus) y Ostrea edulis (Linnaeus). Bol. Inst. Esp. Oceanogr., III(235): 227-234.

Pérez-Camacho, A. - 1980. Biología de Venerupis pullastra (Montagu, 1803) y Venerupis decussata (Linné, 1767) (Mollusca: Bivalvia) con especial referencia a factores determinantes de la producción. Bol. Inst. Esp. Oceanogr., 281: 353-358.

Pérez-Camacho, A., M. Delgado, M.J. Fernández-Reiriz and U. Labarta. - 2003. Energy balance, gonad development and biochemical composition in the clam Ruditapes decussatus. Mar. 
Ecol. Prog. Ser., 258: 133-145.

Pipe, R.K. - 1985. Seasonal cycles and effects of starvation on egg development in Mytilus edulis. Mar. Ecol. Prog. Ser., 24: 121-128.

Rodríguez-Moscoso, E. - 2000. Histofisiología de la reproducción de la almeja fina Ruditapes decussatus (Linné, 1758) en la ría de Arosa (Población natural y población de cultivo). $\mathrm{PhD}$ thesis, Univ. Santiago de Compostela.

Ruíz, C.A., M. Abad, F. Sedane, L.O. García-Martín and J.L. Sánchez-López. - 1992. Influence of seasonal environmental changes on the gamete production and biochemical composition of Crassostrea gigas (Thunberg) in suspended culture in E Grove, Galicia, Spain. J. Exp. Mar. Biol. Ecol., 155: 249-262.

Sastry, A.N. - 1968. The relationship among food, temperature, and gonad development of the bay scallops Aequipecten irradians (Lamarck). Physiol. Zool., 41: 44-53.

Seed, R. - 1976. Ecology. In: B.L. Bayne (ed.), Marine Mussels. Their Ecology and Physiology, pp. 13-65. Cambridge University Press, Cambridge.
Shaffee, M.S. and M. Daouidi. - 1991. Gametogenesis and spawning in the carpet-shell clam, Ruditapes decussatus (L.) (Mollusca: Bivalvia), from the Atlantic coast of Morocco. Aquacult. Fish Manage., 22: 203-216.

Snedecor, G.W. and W.G. Cochran. - 1980. Métodos estadísticos. Cía Ed. Continental, Buenos Aires.

Villalba, A., M.C. López and M.J. Carballal. - 1993. Parásitos y alteraciones patológicas de tres especies de almeja, Ruditapes decussatus, Venerupis pullastra y Venerupis rhomboides, en las rías gallegas. Actas IV Congreso Nacional de Acuicultura (Spain), 551-556.

Xie, Q. and G.M. Burnell. - 1994. A comparative study of the gametogenic cycles of the clams Tapes philippinarum (Adams and Reeve) and Tapes decussatus (Linnaeus) on the south coats of Ireland. J. Shellfish Res., 13(2): 467-472.

Scient. ed.: M. Ramón 
